\title{
HISTOMORPHOLOGICAL SPECTRUM OF BREAST LESIONS
}

\author{
Kiran H. S1, Jayaprakash Shetty2 ${ }^{2}$ Chandrika Rao
}

${ }^{1}$ Assistant Professor, Department of Pathology, Yenepoya Medical College, Mangalore.

2 Professor, Department of Pathology, K. S. Hegde Medical Academy, Mangalore.

${ }^{3}$ Assistant Professor, Department of Pathology, K. S. Hegde Medical Academy, Mangalore.

\section{ABSTRACT}

\section{BACKGROUND}

Cancer of the breast is the second most common cause of cancer in women. Benign or malignant lesions presenting as mass in the breast causes anxiety to the patients and the family members.

\section{AIMS AND OBJECTIVES OF THE STUDY}

1. To classify different types of lesions of breast, both benign and malignant.

2. Histomorphological study of various types of benign and malignant breast lesions.

3. To study spectrum of lesions associated with benign and malignant breast diseases.

\section{SETTING AND DESIGN}

All the breast biopsies, lumpectomies, and mastectomy specimens presenting to Department of Pathology of our institution between June 2012 to June 2014.

\section{MATERIALS AND METHODS}

A sample size of 100 cases are included in this study. Clinical details are taken from records. The specimens of breast sent to the Department of Pathology are processed by routine histopathological techniques. Histopathological features are studied on haematoxylin and eosin-stained sections.

\section{STATISTICAL ANALYSIS}

Statistically, the test of proportion is used to obtain the frequency of all lesions. Chi-square test, which is used to find the association between the spectrum of lesions showed a $\mathrm{p}$ value of 0.0438 and hence the study was considered significant.

\section{RESULTS}

In our study, out of 100 cases, malignant breast lesions constituted the majority of the lesions comprising of 49 cases ( $49 \%$ ), followed by benign lesions comprising 46 cases (46\%) and the inflammatory lesions comprising 5 cases (5\%). Among benign lesions, fibrocystic disease was the predominant lesion comprising of 39 cases (41\%), followed by fibroadenoma comprising 26 cases (28\%), which is followed by 13 cases (14\%) of fibrocystic disease with columnar cell change and 8 cases (9\%) of sclerosing adenosis. Among malignant lesions, invasive ductal carcinoma (NST) type was the most common lesion comprising 31 cases (61\%) followed by 11 cases $(21 \%)$ of invasive lobular carcinoma. Invasive papillary carcinoma and medullary carcinoma comprising of 3 cases (6\%) each and 1 case $(2 \%)$ of metaplastic carcinoma.

\section{CONCLUSION}

In the present study, we conclude that the benign breast lesions associated with intermediate and high risk epithelial proliferative lesions, which forms the matter of concern since most of them occurring commonly in young females who are in the reproductive age group. Hence, diagnosing these lesions in small breast biopsies, lumpectomies, and excised specimens is of utmost importance and in this regard these must be carefully evaluated.

\section{KEYWORDS}

Benign, Carcinoma, Fibroadenoma, Fibrocystic Disease.

HOW TO CITE THIS ARTICLE: Kiran HS, Shetty J, Rao C. Histomorphological spectrum of breast lesions. J. Evolution Med. Dent. Sci. 2016;5(54):3577-3581, DOI: 10.14260/jemds/2016/825

\section{INTRODUCTION}

Breast is an organ, which is constantly under the influence of sex hormones, is one of the commonest site of neoplasm in the human body.

Financial or Other, Competing Interest: None.

Submission 19-05-2016, Peer Review 22-06-2016,

Acceptance 27-06-2016, Published 05-07-2016.

Corresponding Author:

Dr. Kiran H.S,

Assistant Professor,

No.14, $1^{\text {ST }}$ Block, $1^{\text {ST }}$ Main Road

Shakthi Nagar, Mysore-570019.

E-mail: drkiranhs22@gmail.com

DOI: $10.14260 /$ jemds $/ 2016 / 825$
Its during adolescent and reproductive age groups, major hormonal changes produce morphological and functional alterations in mammary gland, which directly or indirectly affects the disease pattern.

Breast Cancer is the second most common cause of cancer in women. Of all the breast disorders, palpable breast lump is the most common manifestation. All the breast lumps are suspected to be carcinomas until proved otherwise.

The most common causes of breast lump are fibrocystic change, fibroadenoma, and the carcinoma of breast in the ascending order. ${ }^{1} 10$-year retrospective analysis of all breast data showed $64.2 \%$ benign and $35.7 \%$ malignant breast 
lesions. ${ }^{2}$ The peak age for patients with benign breast disease was 21-30 years and that for breast cancer was 41-50 years.

This study aims at diagnosing and finding the incidence of broad spectrum of breast disorders such as fibrocystic disease, fibroadenoma, and neoplastic disorders with respect to different age groups and the spectrum of epithelial proliferative lesions associated with benign and malignant breast diseases, in the biopsy specimens, lumpectomies, and mastectomy specimens along with lymph nodes, which are received to the Department of Pathology of our institution.

\section{MATERIALS AND METHODS}

The present histopathological study includes a detailed analysis of sample size of 100 cases i.e. breast biopsies, lumpectomies, and mastectomy specimens presenting to Department of Pathology of our institution between June 2012 to June 2014. It is a prospective study.

The age, presenting complaints, and other relevant clinical data were recorded. Only female patients of all age groups are considered for the present study.

\section{Sample Size}

100 cases.

\section{METHODOLOGY}

The tissue samples were received in $10 \%$ buffered formalin and processed. The excised breast biopsy specimens, lumpectomies, and the mastectomy specimens received during the study period are taken. Photographs of the classical specimen were taken. Specimens were examined grossly for their size, shape, colour, and consistency. Changes in the nipple and skin and the presence of lymph nodes were also noted wherever relevant.

In modified radical mastectomy specimens, as many nodes as possible were dissected out in fresh state and their number and size were noted. Mastectomy specimens were cut serially at a distance of 2-3 cms. Cut surfaces were noted for tumour, colour, consistency, size, extension, involvement of the skin, chest wall and secondary changes such as necrosis, cystic degeneration, haemorrhage, and fibrosis.

Multiple bits were taken from the tumour proper, its margins, nipple, and lymph nodes and the smaller ones fully submitted for processing by paraffin embedding. Appropriate number of sections of 4-5 micron thick tissue sections were cut and stained routinely with Haematoxylin and Eosin (H and E).

\section{STATISTICAL ANALYSIS}

The histopathology slides were examined and final diagnosis was made. Findings of this study were tabulated and statistically analysed. All the data are entered in SPSS 17.0 and analysed. Test of proportion was used to obtain frequency and percentage of lesions. Chi-square test was used to find association between spectrum of lesions.

\section{RESULTS}

The present study of histomorphological spectrum of breast lesions was carried out at the Department of Pathology of our institution from June 2012 to June 2014 for over a period of 24 months and was based on a sample of 100 cases.

Cases from all the age groups were analysed in the study. Various breast lesions were diagnosed by detailed histopathological examination of tissue sections.

In our present study, the most common presenting complaint is breast lump comprising of 79 cases (79\%), followed by the complaint, lump associated with pain in 14 cases $(14 \%), 2$ cases $(2 \%)$ presented with only diffuse pain in the breast, 4 cases (4\%) presented with bloody nipple discharge and 1 case (1\%) presented with skin ulceration of the breast. (Table 1).

\begin{tabular}{|c|c|c|c|}
\hline $\begin{array}{l}\text { Sl. } \\
\text { No. }\end{array}$ & $\begin{array}{l}\text { Presenting } \\
\text { Complaint }\end{array}$ & $\begin{array}{l}\text { No. of } \\
\text { Cases }\end{array}$ & $\%$ \\
\hline 1 & Breast Lump & 79 & $79 \%$ \\
\hline 2 & Breast Lump with Pain & 14 & $14 \%$ \\
\hline 3 & Diffuse Pain & 2 & $2 \%$ \\
\hline 4 & Bloody Nipple Discharge & 4 & $4 \%$ \\
\hline \multirow[t]{2}{*}{5} & Skin Ulceration & 1 & $1 \%$ \\
\hline & Total & 100 & $100 \%$ \\
\hline \multicolumn{4}{|c|}{$\begin{array}{c}\text { Table 1: Showing the Incidence } \\
\text { of Presenting Complaints }\end{array}$} \\
\hline
\end{tabular}

Of the 100 breast specimens, 95 cases (95\%) were diagnosed as neoplastic lesions, and 5 (5\%) were nonneoplastic lesions. (Figure 1)

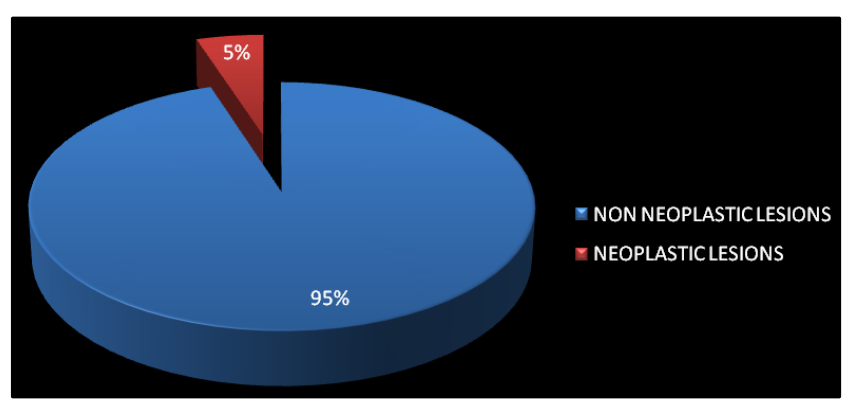

Fig. 1: PIE Chart Showing Distribution of Neoplastic and Non-Neoplastic Lesions of Breast

Out of 95 neoplastic lesions, 46 cases were diagnosed as benign lesions and 49 cases as malignant lesions, which constituted $48 \%$ and $52 \%$ respectively (Table 2 ).

\begin{tabular}{|c|c|c|c|}
\hline Sl. No. & Lesions & Frequency & $\%$ \\
\hline 1 & Benign & 46 & $48 \%$ \\
\hline 2 & Malignant & 49 & $52 \%$ \\
\hline & Total & 95 & $100 \%$ \\
\hline \multicolumn{4}{|c|}{$\begin{array}{l}\text { Table 2: Incidence of Benign and } \\
\text { Malignant Lesions of Breast }\end{array}$} \\
\hline
\end{tabular}

In the present study, fibrocystic disease is the predominant benign lesion comprising 39 cases (41\%), followed by fibroadenoma 26 cases (28\%), fibrocystic disease with columnar cell change 13 cases (14\%), sclerosing adenosis 8 cases (8\%), intraductal papilloma 5 cases $(5 \%)$, apocrine adenoma 3 cases $(3 \%)$, benign phyllodes 1 case $(1 \%)$ (Figure 2). 


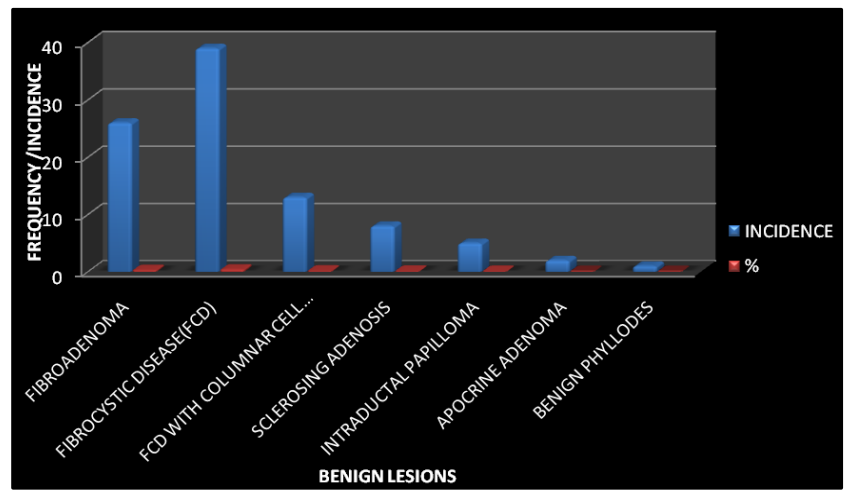

Fig. 2: Bar Diagram Showing Distribution Pattern of Benign Lesions of Breast

Among malignant lesions, invasive ductal carcinoma-NST type was the most common type constituting 31 cases (61\%), followed by infiltrating lobular carcinoma 11 cases (21\%), invasive papillary carcinoma 3 cases $(6 \%)$, medullary carcinoma 3 cases $(6 \%)$ with mixed IDC and ILC, carcinoma with neuroendocrine differentiation, and metaplastic carcinoma 1 case (2\%) each (Table 3 ).

\begin{tabular}{|c|c|c|c|}
\hline $\begin{array}{l}\text { Sl. } \\
\text { No. }\end{array}$ & $\begin{array}{c}\text { Malignant } \\
\text { Lesions }\end{array}$ & Frequency & $\%$ \\
\hline 1 & $\begin{array}{c}\text { Invasive Ductal } \\
\text { Carcinoma (IDC)-NST }\end{array}$ & 31 & $61 \%$ \\
\hline 2 & $\begin{array}{l}\text { Invasive Lobular } \\
\text { Carcinoma (ILC) }\end{array}$ & 11 & $21 \%$ \\
\hline 3 & IDC+ ILC & 1 & $2 \%$ \\
\hline 4 & $\begin{array}{c}\text { Invasive Papillary } \\
\text { Carcinoma }\end{array}$ & 3 & $6 \%$ \\
\hline 5 & Medullary Carcinoma & 3 & $6 \%$ \\
\hline 6 & $\begin{array}{l}\text { Carcinoma with } \\
\text { Neuroendocrine } \\
\text { Differentiation }\end{array}$ & 1 & $2 \%$ \\
\hline \multirow[t]{2}{*}{7} & Metaplastic Carcinoma & 1 & $2 \%$ \\
\hline & Total & 51 & $100 \%$ \\
\hline
\end{tabular}

Statistically, the test of proportion is used to obtain the frequency of all lesions. Chi-square test, which is used to find the association between the spectrum of lesions showed a $p$ value of 0.0438 and hence the study was considered significant.

\section{DISCUSSION}

Our study conducted from June 2012 to June 2014, the clinical history, gross, and histopathological examination of breast specimens of all the 100 cases are collected and analysed. Out of 100 cases, 46 cases are found to be benign lesions, 49 cases are malignant lesions, and the remaining 5 cases are nonneoplastic or inflammatory lesions.

Fibrocystic disease and fibroadenoma were the most common benign lesions commonly occurring in the age range of 40-50 years and 20-30 years respectively.

Among the malignant lesions, invasive ductal carcinomano special type (IDC-NST) is the most common malignant lesion. It occurred in females of the age group 40-50 years. In the study of Parajuli S et al (2011), benign lesions constituted about $85 \%$ of lesion, malignant constituted about $12 \%$ and the remaining $3 \%$ of lesions were inflammatory.

The peak age incidence of benign lesion is in between 2130 years and the malignant lesions in between $31-50$ years. In his study, also fibroadenoma and fibrocystic disease were the most common benign lesions and infiltrating ductal carcinoma was the most common malignant lesion.

In Samir S et al (1995). ${ }^{3}$ study majority of cases are nonneoplastic lesions i.e. 56 cases (51.9\%) and neoplastic lesions comprised 52 cases (48.1\%). In the study conducted by M S Siddiqui et al (2003) $)^{4}$ out of 3279 cases, majority i.e., 2357 cases were diagnosed as neoplastic lesions and 922 cases (28.2\%) were non-neoplastic lesions. In the study conducted by Naseer Ahmed Shaik et al (2012). ${ }^{5}$ out of 2693 cases, 2186 cases (81.1\%) were neoplastic lesions and 507 cases (18.83\%) were non-neoplastic lesions.

In our study, we have found neoplastic lesions as majority with 95 cases (95\%) and only 5 cases (5\%) of non-neoplastic or inflammatory lesions.

Our study was in concordance with the other two studies with majority being the neoplastic lesions when compared to non-neoplastic lesions. (Table 4)

\begin{tabular}{|c|c|c|c|c|c|}
\hline \multirow{2}{*}{$\begin{array}{c}\text { Sl. } \\
\text { No. }\end{array}$} & \multirow{2}{*}{ Study } & \multicolumn{2}{|c|}{$\begin{array}{c}\text { Neoplastic } \\
\text { Lesions }\end{array}$} & $\begin{array}{c}\text { Non-Neoplastic } \\
\text { Lesions }\end{array}$ \\
\cline { 3 - 6 } & $\begin{array}{c}\text { No. of } \\
\text { Cases }\end{array}$ & $\%$ & $\begin{array}{c}\text { No. of } \\
\text { Cases }\end{array}$ & $\%$ \\
\hline 1 & $\begin{array}{c}\text { Samir S et al } \\
(1995) .^{3}\end{array}$ & 52 & $48.1 \%$ & 56 & $51.9 \%$ \\
\hline 2 & $\begin{array}{c}\text { M S Siddiqui } \\
\text { et al } \\
(2003) .4\end{array}$ & 2357 & $71.8 \%$ & 922 & $28.2 \%$ \\
\hline \multirow{2}{*}{3} & $\begin{array}{c}\text { Naseer } \\
\text { Ahmed } \\
\text { Shaik et al } \\
(2012) .5\end{array}$ & 2186 & $81 \%$ & 507 & $18.83 \%$ \\
\hline 4 & $\begin{array}{c}\text { Present } \\
\text { study }\end{array}$ & 95 & $95 \%$ & 5 & $5 \%$ \\
\hline \multicolumn{7}{|c|}{$\begin{array}{c}\text { Table 4: Comparison of Incidence of Neoplastic } \\
\text { and Non-Neoplastic Lesions }\end{array}$} \\
\hline
\end{tabular}

In the study conducted by Khanna R et al (1998).6, which involved a study of 1315 cases, benign lesions comprised 807 (61.4\%) and malignant lesions comprising 508 cases (39.6\%). Two more similar studies i.e. Tarek Tawfik et al (2009) ${ }^{7}$ had out of 969 cases majority were benign lesions comprising of 583 cases $(60.2 \%)$ and malignant lesions comprising of 207 cases (21.3\%). Other study by Parajuli S et al (2011). ${ }^{8}$ Which had out of 114 cases, 100 cases (87\%) of benign lesions and 14 cases (13\%) of malignant lesions.

In our study, among the 95 neoplastic lesions, benign lesions comprised about 46 cases i.e. $48.4 \%$ of neoplastic lesions and malignant lesions comprised of 49 cases (51.5\%). When compared to all the above 3 studies in which the benign lesions form the majority, our study has predominantly malignant lesions (Table 5). 


\begin{tabular}{|c|c|c|c|c|c|c|}
\hline \multirow{2}{*}{$\begin{array}{c}\text { Sl. } \\
\text { No. }\end{array}$} & Study & $\begin{array}{c}\text { Total } \\
\text { No. of } \\
\text { Cases }\end{array}$ & No. & \% & No. & $\%$ \\
\hline 1 & $\begin{array}{c}\text { Khanna R } \\
\text { et al } \\
(1998) .6\end{array}$ & 1315 & 807 & $61.4 \%$ & 508 & $39.6 \%$ \\
\hline 2 & $\begin{array}{c}\text { Tarek } \\
\text { Tawfik et al } \\
(2009)^{7}\end{array}$ & 969 & 583 & $60.2 \%$ & 207 & $21.3 \%$ \\
\hline 3 & $\begin{array}{c}\text { Parajuli S } \\
\text { et al } \\
(2011) .8\end{array}$ & 114 & 100 & $87 \%$ & 14 & $13 \%$ \\
\hline 4 & $\begin{array}{c}\text { Present } \\
\text { study(2014) }\end{array}$ & 100 & 46 & $48.4 \%$ & 49 & $51.5 \%$ \\
\hline \multicolumn{7}{|c|}{$\begin{array}{c}\text { Table 5: Comparison of Incidence of Benign } \\
\text { and Malignant Neoplasms }\end{array}$} \\
\hline
\end{tabular}

In Tarek Tawfik Amin et al (2009). ${ }^{7}$ study, fibrocystic disease was the commonest lesion to be associated with usual ductal hyperplasia comprising of about 73 cases $(40.1 \%)$, followed by fibroadenoma with UDH of 46 cases (15.9\%), sclerosing adenosis with UDH of 21 cases (13.3\%), intraductal papilloma with UDH of about 6 cases (3.8\%) and simple adenosis with usual lobular hyperplasia (ULH) of 10 cases $(2.5 \%)$. In our study, the benign lesions were commonly associated with the epithelial proliferative lesions without atypia. Among the benign lesions, fibroadenoma the second commonest benign lesion in our study was most commonly associated with usual hyperplasia of ductal type or usual ductal hyperplasia (UDH) constituting about 14 cases (36.8\%), followed by fibrocystic lesion with usual ductal hyperplasia comprising 13 cases (34.2\%), fibrocystic disease with columnar cell change associated with usual ductal hyperplasia in 8 cases (21\%), followed by sclerosing adenosis with UDH in 2 cases (5.2\%), intraductal papilloma with UDH, and simple adenosis with usual lobular hyperplasia (ULH) comprised 1 case $(2.6 \%)$ each (Table 6).

\begin{tabular}{|c|c|c|c|}
\hline \multirow{2}{*}{$\begin{array}{c}\text { Sl. } \\
\text { No. }\end{array}$} & Lesions & $\begin{array}{c}\text { Tarek } \\
\text { Tawfik Amin } \\
\text { et al (2009). }\end{array}$ & $\begin{array}{c}\text { Present } \\
\text { Study } \\
(\mathbf{2 0 1 4})\end{array}$ \\
\cline { 3 - 4 } & No. (\%) & No. (\%) \\
\hline 1 & $\begin{array}{c}\text { Fibroadenoma with } \\
\text { Usual Ductal } \\
\text { Hyperplasia (UDH) }\end{array}$ & $46(15.9 \%)$ & $\begin{array}{c}14 \\
(36.8 \%)\end{array}$ \\
\hline 2 & $\begin{array}{c}\text { Fibrocystic disease } \\
\text { with UDH }\end{array}$ & $73(40.1 \%)$ & $\begin{array}{c}13 \\
(34.2 \%)\end{array}$ \\
\hline 3 & $\begin{array}{c}\text { Sclerosing adenosis } \\
\text { with UDH }\end{array}$ & $21(13.3 \%)$ & $2(5.2 \%)$ \\
\hline 4 & $\begin{array}{c}\text { Intraductal papilloma } \\
\text { with UDH }\end{array}$ & $6(3.8 \%)$ & $1(2.6 \%)$ \\
\hline 5 & $\begin{array}{c}\text { FCD with columnar } \\
\text { cell change with UDH }\end{array}$ & $8(21 \%)$ \\
\hline 5 & $\begin{array}{c}\text { Adenosis with Usual } \\
\text { Lobular Hyperplasia } \\
\text { (ULH) }\end{array}$ & $10(2.5 \%)$ & $1(2.6 \%)$ \\
\hline \multicolumn{3}{|c|}{$\begin{array}{c}\text { Table 6: Comparison of Association of Benign Lesions } \\
\text { with Epithelial Proliferative Lesions Without Atypia }\end{array}$} \\
\hline \multicolumn{3}{|c|}{}
\end{tabular}

In Tarek Tawfik Amin et al (2009). ${ }^{7}$ study, fibrocystic disease was the commonest lesion to be associated with atypical ductal hyperplasia comprising of about 13 cases (30.2\%), followed by fibroadenoma with ADH of 12 cases (27.9\%), apocrine adenosis with ADH of 6 cases (14\%), sclerosing adenosis and intraductal papilloma constituted about 4 cases (9.3\%) each in association with ADH.

In our present study, the benign lesions are also seen in associated with the epithelial proliferative lesions with atypia, among the benign lesions the commonest benign lesion fibrocystic disease was mostly associated with atypical hyperplasia of ductal type or atypical ductal hyperplasia (ADH) constituting about 4 cases (28.5\%), followed by fibrocystic disease with columnar cell change and intraductal papilloma associated with atypical ductal hyperplasia in 3 cases (21.4\%)each, followed by sclerosing adenosis with ADH and fibroadenoma with ADH of 2 cases(14.2\%) each, simple adenosis with atypical lobular hyperplasia (ALH) comprised 2 cases (14.2\%) (Table 7).

The association of benign lesions with the epithelial proliferative lesions with and without atypia in comparison to other similar studies showed significant concordance.

\begin{tabular}{|c|c|c|c|}
\hline \multirow{2}{*}{$\begin{array}{l}\text { Sl. } \\
\text { No. }\end{array}$} & \multirow[t]{2}{*}{ Lesions } & $\begin{array}{c}\text { Tarek } \\
\text { Tawfik } \\
\text { Amin et al } \\
(2009) .^{7} \\
\end{array}$ & $\begin{array}{l}\text { Present } \\
\text { Study } \\
(2014)\end{array}$ \\
\hline & & No. (\%) & No. (\%) \\
\hline 1 & $\begin{array}{l}\text { Fibroadenoma with } \\
\text { Atypical Ductal } \\
\text { Hyperplasia (ADH) }\end{array}$ & $12(27.9 \%)$ & $2(14.2 \%)$ \\
\hline 2 & $\begin{array}{l}\text { Fibrocystic disease } \\
\text { with ADH }\end{array}$ & $13(30.2 \%)$ & $4(28.5 \%)$ \\
\hline 3 & $\begin{array}{c}\text { Sclerosing adenosis } \\
\text { with ADH }\end{array}$ & $4(9.3 \%)$ & $2(14.2 \%)$ \\
\hline 4 & $\begin{array}{c}\text { Intraductal papilloma } \\
\text { with ADH }\end{array}$ & $4(9.3 \%)$ & $3(21.4 \%)$ \\
\hline 5 & $\begin{array}{l}\text { FCD with columnar } \\
\text { cell change with ADH }\end{array}$ & - & $3(21.4 \%)$ \\
\hline 6 & $\begin{array}{c}\text { Adenosis with } \\
\text { Atypical Lobular } \\
\text { Hyperplasia (ALH) }\end{array}$ & - & $2(14.2 \%)$ \\
\hline 7 & $\begin{array}{l}\text { Apocrine adenosis } \\
\text { with ADH }\end{array}$ & $6(14 \%)$ & - \\
\hline
\end{tabular}

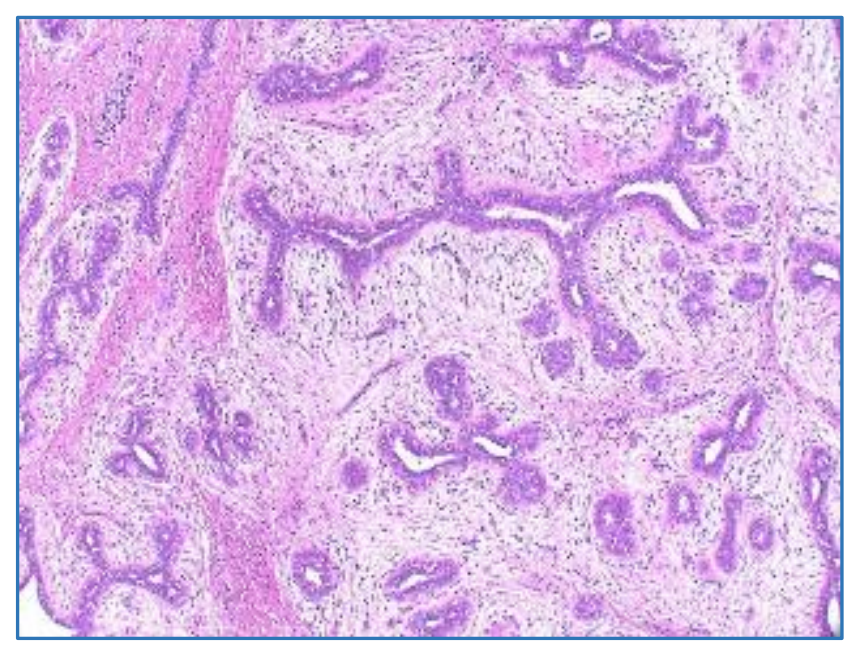

Fig. 3: FIBROADENOMA-Intracanalicular (Arrow) and Pericanalicular Pattern with Mild Stromal Hyperplasia (H and $E$ 40X). 


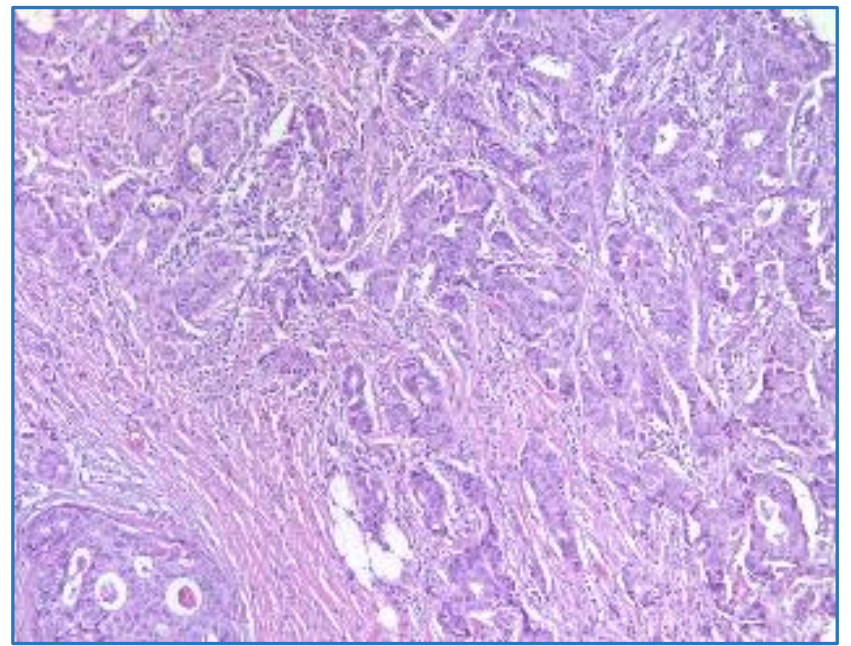

Fig. 4: INVASIVE DUCTAL CARCINOMA (NST) - Tumour Cells in Tubules, Ducts, and Trabeculae Having Moderate Cytoplasm Hyperchromatic Nuclei Prominent Nucleoli Surrounded by a Dense Desmoplastic Stroma. (H and E 40X).

\section{ACKNOWLEDGEMENT}

I would like to express my sincere gratitude to my guide and advisor Dr. Jayaprakash Shetty K, Dr. Chandrika Rao, our technical staff Mrs. Vinaya, Mr. Girish, my parents, and family for the continuous support for my study and research. Above all, I thank God for giving me the strength all along.

\section{REFERENCES}

1. Guray M, Shain AA. Benign breast diseases - classification, diagnosis, and management. The oncologist 2006;11(5):435-49.

2. Shukla HS, Kumar S. Benign breast disorders in nonwestern populations: part II - benign breast disorders in India. World J surg 1989;13:746-9.

3. Samir S, Sadi ARM, Ilahi F, et al. The spectrum of breast diseases in Saudi Arab females a 23 year pathological survey at Dhahran Health Centre. Ann Saudi Med 1995;15(2):125-32.

4. Siddiqui MS, Kayani N, Gill MS, et al. Breast diseases: a histopathological analysis of 3279 cases at a tertiary care centre in Pakistan. JPMA 2003;53(3):94-7.

5. Sheik NA, Chang F, Ikram-ud-din U, et al. Breast diseases pattern at lumps 10 years experience of consecutive referrals to public sector Medical University at Hyderabad. Professional Medical J 2012;19(3):1-4.

6. Khanna R, Khanna S, Chathurvedi S, et al. Spectrum of diseases in young females: a retrospective study of 1315 patients. Indian J Pathol Microbiol 1998;41(4):397-401.

7. Amin TT, Al-Mulhim AR, Chopra R. Histopathological patterns and risk of female breast lesions at a secondary level of care in Saudi Arabia. Asian Pac J Cancer Prev 2009;10(6):1121-6.

8. Parajuli S, Koirala U, Khatri R, et al. Histomorphological spectrum of breast lesions. J Nepal Health Res Counc 2011;9(1):48-51. 